\title{
TIMING OF LARVAL RELEASE \\ BY REEF CORAL POCILLOPORA DAMICORNIS AT PANJANG ISLAND, CENTRAL JAVA
}

\author{
Munasik $^{1,2, *}$, Suharsono ${ }^{3}$, J. Situmorang ${ }^{1}$, H.N. Kamiso ${ }^{4}$ \\ ${ }^{1}$ Graduate School of Biology, Gadjah Mada University, Yogyakarta \\ ${ }^{2}$ Department of Marine Science, Diponegoro University, Semarang \\ ${ }^{3}$ Research Center for Oceanography, Indonesian Institute of Sciences, Jakarta \\ ${ }^{4}$ Department of Fisheries and Marine Science, Gadjah Mada University, Yogyakarta \\ "e-mail:munasik_motawi@yahoo.com
}

\begin{abstract}
Monthly larval release by the coral Pocillopora damicornis at Panjang Island, Central Java was investigated. Corals were collected from windward and leeward and maintained in outdoor, flow-trough system to quantify nightly release of larvae. Larval release of the coral occurs every month throughout the year, and its planulation increases during dry monsoon. Monthly planulation occurs from new moon to full moon and possesses different pattern between single and paired colonies. Planulation in paired colonies occurred in single peak and more synchronized in each colony, however single colonies planulated in double peaks and less synchronized in each colony. This study confirmed that planulation period of $P$. damicornis at Panjang Island over a range of lunar phases with shorter periods of peak release which predominantly controlling by tidal range rather than lunar cycle.
\end{abstract}

Keywords: Larval release, Reef coral Pocillopora damicornis, Panjang Island,Central Java

\section{INTRODUCTION}

The coral reefs of Indonesia are the most diverse in the world (Veron, 2000) however the recent status of the coral reef has depleted (Suharsono, 2004). Anthropogenic threats are severe including run off and sediments from land based activities and destructive fishing practices. Coral reef rehabilitation and management program particularly promoting the potential for natural recovery by a pioneer coral are needed. One kind of pioneer corals that has rapid development and wide distribution is Pocillopora damicornis (Endean and Cameron, 1990) Reproductive biology of the species has been widely studied throughout the Indo-Pacific (Harrison and Wallace, 1990), however the reproductive patterns of the species are still unclear, particularly the patterns of lunar periodicity are not consistent among locations. Reproductive periodicity of corals may vary with locations, both latitudinal and from reef area to reef area (Stimson, 1978; Rinkevich and Loya, 1979), and may have an underlying seasonal pattern (Harriott, 1983; Stoddart and Black, 1985; Tanner, 1996). It is possible that reproductive activities of corals in each region respond to different environmental factors, or that corals in two regions may respond differently to the similar factors.

Many environmental factors have been suggested to be responsible for controlling aspects of reproduction in corals, including temperature, photoperiod, lunar phase, tides and water movement (Harrison and Wallace, 1990). Water temperature has been implicated in determining the initiation and conclusion of seasonal reproductive periods for many marine organisms (Giese and Pearse, 1974). Additionally, photoperiod is known to regulate flowering in many terrestrial plants, and may play a similar role in initiating gonad development and/or spawning in marine invertebrates (Babcock et al., 1994). Both latitude and water temperature are major factors determining seasonal variation in reproduction of 
coral P. damicornis. However, the lunar periodicity in planulation of the coral is still unclear. Local scale of experimental test between sites within the island are required to determine whether lunar phase, tidal range or other factors act independently and interactively to control monthly reproduction of coral P. damicornis.

This study was designed to investigate the timing of larval release by reef coral Pocillopora damicornis and the role of environmental factors that influence its reproduction at Panjang Island, Central Java.

\section{MATERIALS AND METHODS}

Eighteen colonies of Pocillopora damicornis $(18.7 \pm 2.1 \mathrm{~cm}$ in diameter) were collected from leeward and windward of Panjang Island, Central Java (6 $\left.6^{\circ} 34^{\prime} \mathrm{S} ; 110^{\circ} 37^{\prime} 45^{\prime \prime} \mathrm{E}\right)$ a week prior to new moon. Colonies were transported to the Marine Station of Diponegoro University, Teluk Awur Jepara (about $4.6 \mathrm{~km}$ from Panjang Island Jepara) and transferred into 12 buckets using a flow-through of outdoor seawater system. Overflow from the buckets was diverted into collector cups (planula collector) constructed from plastic beaker bases built up with walls of $180 \mu \mathrm{m}$ mesh plankton netting. Planula larvae were counted by washing the contents of the collector cups onto a grid $180 \mu \mathrm{m}$ mesh sieve. Preliminary observation revealed that larval release occurs only at night for the species. Each morning, the larvae in each collector were collected and counted using a pipette until planulae release ceased. Monthly larval release in aquaria was monitored for a single colony and paired colonies from May 2005 to January 2006. Afterward, the observation of planulae release was ceased due to most of colonies died during heavy rain in Jepara waters. The high rainfall during January resulted in decreasing water salinity into $17 \%$ on January 29.

Water temperature and salinity adjacent to the collection reef were monitored biweekly and monthly during the period and tidal range was calculated from data recorded by Coastal Fisheries Laboratory, Diponegoro University, where the location closest to the collection reefs. Lunar phase data was obtained from fraction of the moon illuminated data which were downloaded from US Naval Observatory Astronomical Applications Department website, http://
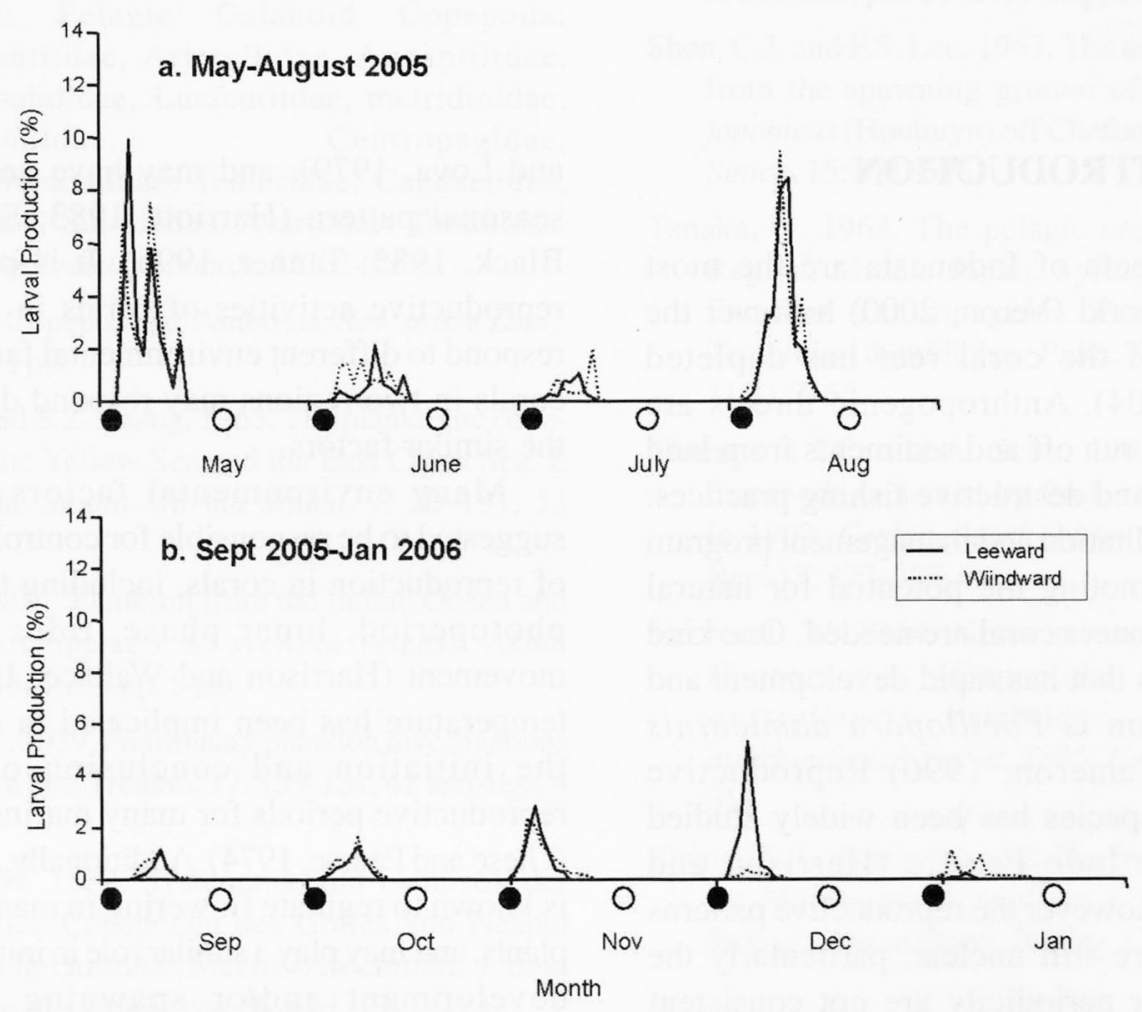

Figure 1. Percentage of larval production from single colonies of Pocillopora damicornis kept in aquaria during period Mei 2005-Januari 2006

( = New moon, $\mathrm{O}=$ Full moon $)$. 
aa.usno.navy.mil. While photoperiod data was downloaded from Daylength and Photoperiod websites, http://www.qpais.co.uk/ modbiec/ dayleng.htm. Rainfall was obtained from data recorded by Station Meteorology in Semarang. The data on daily larva production of single colony, fraction of the moon illuminated, tidal range and daily rainfall were subjected to multiple regression analysis using the general linear model of S-PLUS statistical package.

\section{RESULTS}

Monthly larval release of coral $P$. damicornis occurred from May 2005 to January 2006. The monthly cycles of larval production were irregular (Fig. 1), with several peaks on May and August. While the cycles of paired colonies from leeward had rather regular than others (Fig. 2). The larvae were released from new moon to the full moon, with different pattern of planulation between single and paired colonies. Single colonies releasing planulae on day 3-4 after new moon and around first quarter moon, while paired colonies have a peak in release around first quarter moon (Fig 3). Data from all months were summed and the proportion of colonies releasing larvae over time was plotted; the majority of larval release occurred from day 1 to 16 . The single colonies which collected from windward showed less synchronized in larval release than leeward colonies (Fig 4), while larval release in both paired colonies in leeward and windward were synchronized (Fig. 5 ). On average, each colony from windward released larvae over $9.6 \pm 2.4$ nights while colony from leeward released larva over $7.5 \pm 2.6$ nights. The duration of monthly larval release also showed that single colonies in windward releasing larvae were longer than in leeward, indicating that colonies in windward appeared to be producing larvae by self-fertilization.

Number of larvae released varied significantly between locations $(\mathrm{P}<0.01)$. Colonies from leeward have released more larvae than windward colonies. Single and paired colonies from leeward released larvae respectively $311 \pm 449$ and $604 \pm$ 744 individuals/day, whereas the larval production of both single and paired colonies from windward respectively $224 \pm 388$ and $455 \pm 431$ individuals/ day. The result indicate that spatial variation (between leeward and windward) in reproduction appears to occur in larval production.

Multiple regression analysis showed a significant $(\mathrm{P}<0.01)$ relationship between tides, lunar and rainfall and number of larva each day (Table 1 and 2). Maximal tidal range probably act to synchronize the larval release that the highest larval production occurred on the neap tide in $\mathrm{Au}$ gust when tidal range was minimal.

\section{DISCUSSION}

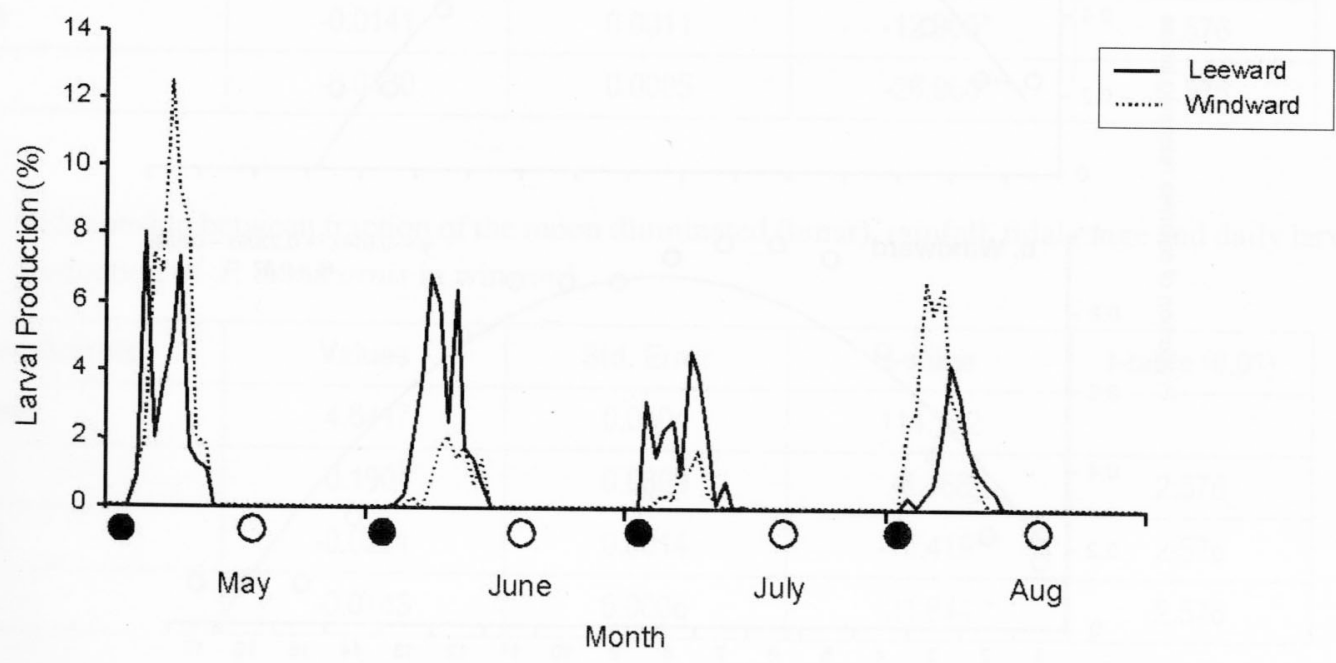

Figure 2. Percentage of larval production from paired colonies of Pocillopora damicornis kept in aquaria during period Mei 2005-Januari 2006

$(\mathrm{O}=$ New moon, $\mathrm{O}=$ Full moon $)$. 

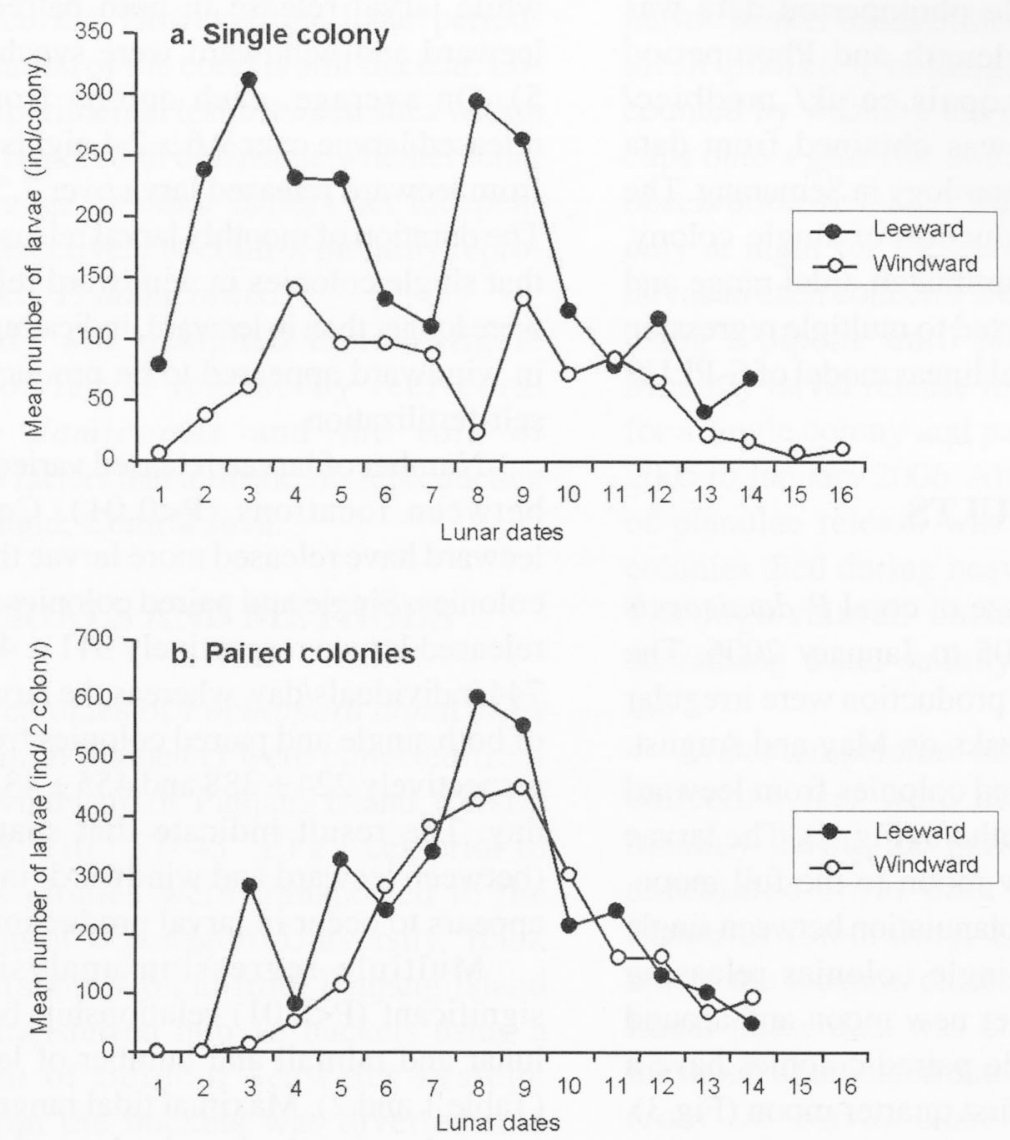

Figure 3. Mean number of larval released in each colony of Pocillopora damicornis (a. single colonies; b. paired colonies)

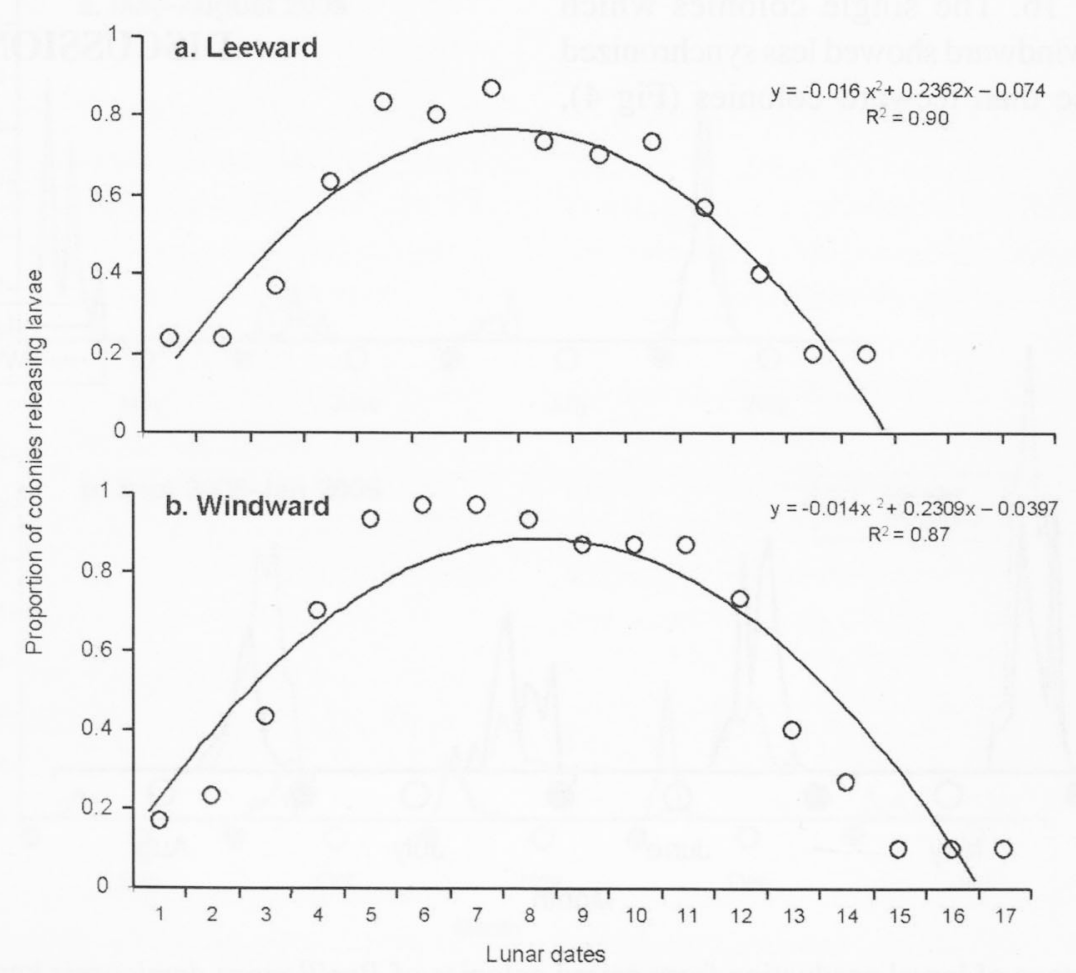

Figure 4. Relationship between lunar day and larval release by single colonies Pocillopora damicornis (a: Leeward, b: Windward) 


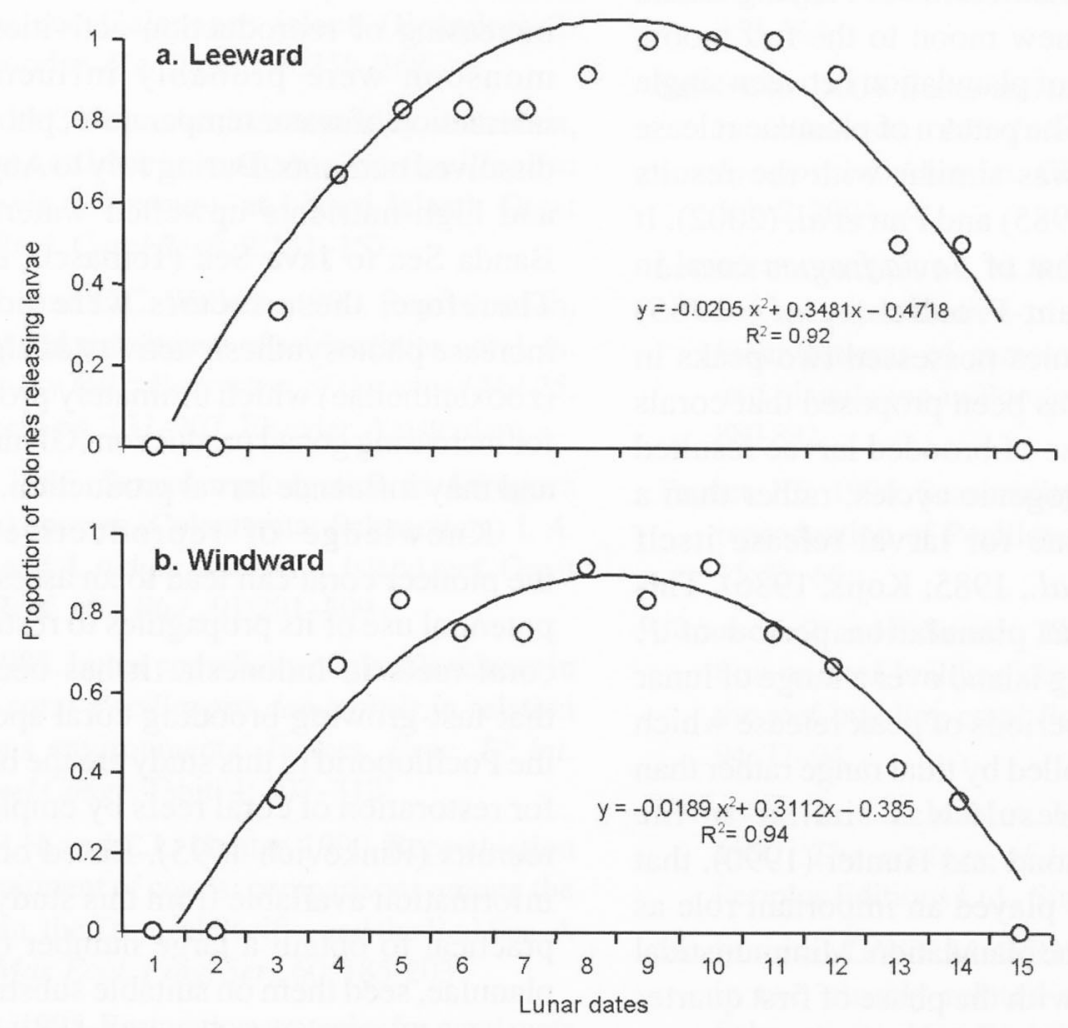

Figure 5. Relationship between lunar day and larval release by paired colonies Pocillopora damicornis (a: Leeward, b: Windward)

Table 1. Relationship between fraction of the moon illuminated (lunar), rainfall, tidal range and daily larval production of $P$. damicornis in leeward

\begin{tabular}{|l|c|c|c|c|}
\hline Coefficients & Values & Std. Error & t-value & t-table (0.01) \\
\hline (Intercept) & 5.0436 & 0.0339 & 148.944 & \\
\hline Lunar & -0.5818 & 0.0265 & $-21.907^{\star *}$ & 2.576 \\
\hline Rainfall & -0.0141 & 0.0011 & $-12.900^{*}$ & 2.576 \\
\hline Tide & -0.0130 & 0.0005 & $-26.960^{\star \star *}$ & 2.576 \\
\hline
\end{tabular}

Table 2. Relationship between fraction of the moon illuminated (lunar), rainfall, tidal range and daily larval production of P. damicornis in winward

\begin{tabular}{|l|c|c|c|c|}
\hline \multicolumn{1}{|c|}{ Coefficients } & Values & Std. Error & t-value & t-table (0.01) \\
\hline (Intercept) & 4.6417 & 0.0404 & 114.752 & \\
\hline Lunar & -0.1904 & 0.0309 & $-6.168^{*}$ & 2.576 \\
\hline Rainfall & -0.0221 & 0.0014 & $-15.419^{* *}$ & 2.576 \\
\hline Tide & -0.0143 & 0.0006 & $-24.844^{* *}$ & 2.576 \\
\hline
\end{tabular}


The larvae of P. damicornis at Panjang Island were released from new moon to the full moon, with different pattern of planulation between single and paired colonies. The pattern of planulae release by paired colonies was similar with the results reported by Jokiel (1985) and Fan et al. (2002). It was also similar to that of Favia fragum coral in Puerto Rico (Szmant-Froelich et al., 1985) however single colonies possessed two peaks in planulae release. It has been proposed that corals have a cyclical release of brooded larvae resulted from multiple gametogenic cycles, rather than a response to some cue for larval release itself (Szmant-Froelich et al., 1985; Kojis, 1986). This study confirmed that planulation period of $P$. damicornis at Panjang Island over a range of lunar phases with shorter periods of peak release which predominantly controlled by tidal range rather than lunar cycle. This result was similar to the suggestion of Richmond and Hunter (1990), that the tide significantly played an important role as stimulating factor in the planulation. Minimum tidal range in accordance with the phase of first quarter moon has resulted in the highest number of larvae in August with minimum rainfall. We suggest that tides acting to synchronize the planulae release while timing of gametes maturation to be more closely synchronized with the lunar cycle than the timing of planulation.

Larval production per colony was higher in leeward than in windward, probably in response to reduce number of polyp productive in windward which might cause most of branches of the coral frequently broken by wave actions. Zakai et al. (2000) reported that larval production by broken colonies of $P$. damicornis were reduced due to lost of their productive tissues. Tomascik and Sander (1987) have proposed that coral $P$. porites from polluted reef are allocated to male, while $P$. damicornis was found in shallow-water possessed strategy by producing more larvae (Stimson, 1978; Van Moorsel, 1983). We suggest that colonies in the windward where physical environment is usually harsh cause stress in corals and result in lowered larval production.

Brooding coral $P$. damicornis at Panjang Island possessed a temporal variation in planulation. Planulation cycle occurred year round and it generally increased in May and August, and showed small increasing in December. The small increasing of planulation only occurred in leeward during December, indicated planulation of the coral was seasonally affected by wave actions. The increasing of reproduction activities during dry monsoon were probably influenced by the interaction of water temperature, photoperiod and dissolved nutrients. During July to August, the cool and high-nutrients upwelled waters flow from Banda Sea to Java Sea (Tomascik et al., 1997). Therefore, these factors were potentially to increase photosynthesis activity of algae-simbiont (zooxanthellae) which ultimately provides carbon for increasing gonad production (Glynn et al., 1991) and may influence larval production.

Knowledge of reproductive season of the pioneer coral can lead to an assessment of the potential use of its propagules to restore degraded coral reefs in Indonesia. It has been suggested that fast-growing brooding coral species such as the Pocilloporid in this study are the best candidate for restoration of coral reefs by employing sexual recruits (Rinkevich 1995). Based on planulation information available from this study, it would be practical to obtain a large number of competent planulae, seed them on suitable substrata, and then transfer them to reefs for restoring damaged coral reefs.

Acknowledgements. This research was conducted as a part of a dissertation submitted to the Gadjah Mada University, Yogyakarta. The authors thanks Ryan Zakaria and Deddy Dwianto for assistance in the field. Funding for this research was profided by SEAMEO-SEARCA scholarship.

\section{REFERENCES}

Babcock, R.C., B.L. Willis, C.J. Simpson.1994. Mass spawning of corals on high latitude coral reef. Coral Reefs, 13: 161-169.

Endean, R. and A.M. Cameron. 1990. Trends and new perspective in coral-reef ecology, In. Z. Dubinsky(ed): Ecosystem of the world Vol 25, Coral Reefs, pp. 469-492. Elsevier, Amsterdam.

Fan, T.Y., J.J. Li, S.X. Ie, L.S. Fang. 2002. Lunar periodicity of larval release by Pocilloporid corals in Southern Taiwan. Zoological Studies, 41(3): 288294.

Giese, A.C. and J.S. Pearse. 1974. Introduction: General principles. In. A.C. Giese and J.S. Pearse (eds): Reproduction of marine invertebrates, I, pp.1-49. Academic Press, New York.

Glynn, P.W., N.J. Gassman, C.M. Eakin, J. Cortes, D.B. Smith, and H.M. Guzman. 1991. Reef coral 
reproduction in the eastern Pasific: Costa Rica, Panama, and Galapagos Island (Ecuador), I. Pocilloporidae. Mar Biol., 109:355-368.

Harriott, V.J. 1983. Reproductive seasonality, settlement, and post-settlement mortality of Pocillopora damicornis (Linnaeus), at Lizard Island, Great Barrier Reef. Coral Reefs, 2:151-157.

Harrison, P.L. and C.C. Wallace. 1990. Reproduction, dispersal and recruitment of scleractinian coral. In. Z. Dubinsky (ed): Ecosystem of the world Vol 25, Coral reefs, pp. 133-207. Elsevier, Amsterdam.

Kojis, B.L. 1986. Sexual reproduction in Acropora (Isopora) species (Colenterata: Scleractinia) I. A. cuneata and A. palifera on Heron Island reef, Great Barrier Reef. Mar Biol., 91:291-309

Jokiel, P.L. 1985. Lunar periodicity of planula release in the reef coral Pocillopora damicornis in relation to various environmental factors. Proc. $5^{\text {th }}$ Int. Coral Reef Congr, Tahiti 4: 307-312.

Richmond, R.H. and C.L. Hunter. 1990. Reproduction and recruitment of corals: comparisons among the Caribbean, the Tropical Pacific, and the Red Sea. A review. Mar. Ecol. Prog. Ser., 60: 185-203.

Rinkevich, B. 1995. Restoration strategies for coral reefs damaged by recreational activities: the use of sexual and asexual recruits. Restor. Ecol., 3: 241251 .

Rinkevich, B and Y Loya. 1979. The reproduction of the Red Sea Coral Stylophora pistillata. II. Synchronization in Breeding and Seasonality of Planulae Sheding. Mar Ecol Prog Ser., 1: 145-152.

Stimson, J. 1978. Mode and timing of reproduction in some hermatypic corals of Hawaii, and Enewetak. Mar Biol., 48:173-184.

Stoddart, J.A. and R. Black. 1985. Cycles of gametogenesis and planulation in the coral
Pocillopora damicornis. Mar Ecol Prog Ser., 23: 153-164.

Suharsono. 2004. Status and management of coral reefs in Indonesia. $10^{\text {th }}$ International Coral Reef Symposium. Abstract. Okinawa-Japan, June 28July 2, 2004

Szmant-Froelich, A.M., M. Reutter, and L Riggs. 1985. Sexual reproduction of Favia fragum (Esper): lunar patterns of gametogenesis, embryogenesis and planulation in Puerto Rico. Bul Mar Sci., 37: 880-892.

Tanner, J.E. 1996. Seasonality lunar periodicity in the reproduction of Pocilloporid corals. Coral Reefs, 15: 59-66.

Tomascik, T and F. Sander. 1987. Effect of eutrophication on reef-building corals III. Reproduction of the reef-building coral Porites porites. Mar Biol., 94: 77-94.

Tomascik, T., A.J. Mah, A. Nontji and M.K. Moosa 1997. The ecology of Indonesian Seas, Part I, Periplus Editions Ltd., Singapore. 642pp.

Van Moorsel, G.W.N.M. 1983. Reproductive strategies in two closely related stony corals (Agaricia, Scleractinia). Mar. Ecol. Prog. Ser., 13: 273-283.

Veron, J.E.N. 2000. Coral of the world. Vol. III. Australian Institute of Marine Science and CRR Old Pty Ltd., Queensland, 490pp.

Zakai, D., O. Levy, and N.E. Chadwick-Furman. 2000. Experimental fragmentation reduces sexual reproductive output by the reef-building coral Pocillopora damicornis. Coral Reefs, 19:185-188. 